\title{
Enacted Pedagogical Content Knowledge Profiles of Chemistry Teachers
}

\author{
Hatice Belge Can (Corresponding Author) \\ Department of Mathematics and Science Education \\ Burdur Mehmet Akif Ersoy University, Burdur, Turkey \\ E-mail: hbelgecan@mehmetakif.edu.tr
}

Received: May 13, 2021 Accepted: June 16, 2021 Published: June 28, 2021

doi:10.5296/jei.v7i1.18643 URL: https://doi.org/10.5296/jei.v7i1.18643

\begin{abstract}
This research focuses on chemistry teachers' enacted pedagogical content knowledge (ePCK) in equilibrium in chemical reactions. The enactment dimension of this pedagogical content knowledge (PCK) encompasses enacted knowledge and skills as well as those embedded in practice concerning the Refined Consensus Model of PCK, the most recent PCK model in science education. As ePCK plays out throughout the whole pedagogical cycle, it was conceptualized as to exist in three forms, such that $\mathrm{ePCK}_{\mathrm{P}}, \mathrm{ePCK}_{\mathrm{T}}$, and $\mathrm{ePCK}_{\mathrm{R}}$. While ePCK and $\mathrm{ePCK}_{\mathrm{R}}$ represent the knowledge and skills that a teacher uses for planning and reflecting respectively, $\mathrm{ePCK}_{\mathrm{T}}$ is related to what a teacher does in the classroom. The holistic nature of ePCK was investigated by using multiple data sources in real-life contexts. Specifically, pre-and post-observation interviews and lesson observations were used to elicit ePCK profiles and to provide triangulation. The grand rubric was customized for use both as an interview protocol and as an observational protocol for analyzing all of the three dimensions of ePCK around the analytical parameters of knowledge and skills related to curricular saliency, conceptual teaching strategies, and student understanding of science. Results revealed that chemistry teachers' ePCK profiles are not uniform across planning, teaching, and reflecting phases, ePCK components, and evaluation criteria. Chemistry teachers perform highest in reflection concerning conceptual teaching strategies and lowest in teaching in terms of curricular saliency. Recommendations for science PCK research were shared.
\end{abstract}

Keywords: Refined consensus model, Enacted pedagogical content knowledge, Plan-teach-reflect cycle, Grand rubric, Chemistry teacher

\section{Introduction}

Pedagogical content knowledge (PCK) is a useful construct for explaining how to enhance 
students' science learning (Kind \& Chan, 2019) as teachers with high-quality PCK know 'when to apply a certain strategy in recognition of students' actual learning needs and understanding why a certain teaching approach may be useful in one situation' (van Driel, Berry, \& Meirink, 2014, p. 865). While the position of such an important construct has been acknowledged by the science education community (Hume, Cooper, \& Borowski, 2019) and in several reform documents (e.g., American Association for the Advancement of Science [AAAS], 1993; National Research Council [NRC], 1996), distinct conceptualizations of PCK have appeared among researchers which diminish or even prevent the potential contribution of PCK to policy documents and science classrooms (Chan \& Hume, 2019).

Abell (2007) called for systematic accumulation of knowledge in the field of science PCK and critically analyzed certain articles to inform the field about the common features of PCK in 2008. Regarding the need for consensus understandings on science teachers' PCK, teacher education scholars in various continents have devoted collective efforts through two consecutive summits. Although the first and second PCK summits show serious shifts in terms of their specific purposes (Carlson \& Daehler, 2019), the primary purpose that underlies both of them can be restated as to generate consensual views about the conceptualization, investigation, and interpretation of PCK within the context of science education (Chan \& Hume, 2019). Summits and outcomes of them (i.e., PCK models) are worthy so that research findings consistently build on one another to move the PCK literature forward which in turn informs policy documents, science teaching, and science learning.

\subsection{Theoretical Framework}

Chan and Hume (2019) reviewed empirical studies of individual science teachers' PCK to recognize how PCK is being conceptualized and investigated by science education researchers. Findings of this review shed light on various issues related to the conceptualization and investigation of PCK (e.g., superficial alignments to the consensus model (CM), unclear usage of terminologies, etc.), the knowledge gaps within the current literature (e.g., a need for research that does not omit the teaching phase of the instructional cycle) and "the need to further refine and update the CM" (p. 54), a science PCK model proposed by the first PCK summit participants.

Although $\mathrm{CM}$ is novel in terms of visualizing a distinction between personal PCK and personal PCK and Skills (PCK\&S), and between PCK\&S and Topic Specific Professional Knowledge (TSPK), it remained impractical in making specifics of PCK explicit (Carlson \& Daehler, 2019). In other words, the leading scholars agreed upon various aspects about the nature of PCK construct within the CM whereas how to align their work with the model was not clear for science education researchers. In that sense, the CM can be regarded as an important first attempt for reaching consensual views within the science PCK field but it was limited in explaining feedback loops that had been hypothesized by summit participants to existing among distinct categories of knowledge and skills. This limitation of the CM was acknowledged by Carlson and Daehler (2019), who reported that "the model did not enough to unpack and represent the variables, layers, and complexities of PCK” (pp. 78-79).

As a response, CM has recently been revised and introduced as the Refined Consensus Model 


\section{Ml Macrothink}

(RCM) of PCK, a representation of collective thinking of the second PCK summit participants. One of the main focus of this summit was about enriching and advancing the literature about methodological issues (Carlson \& Daehler, 2019) that may indicate the tension of the current research community as "the development and validation of an instrument for measuring science teachers' PCK" is one of the rising research foci (Chan \& Hume, 2019, p. 42). This trend of research may (most probably) have the power to improve literature by supplying necessary information for filling knowledge gaps (e.g., cause-effect relationships between PCK and other variables) (e.g., Park, Suh, \& Seo, 2018) that correspondingly serve to the main purpose of informing policy documents and science teaching practices.

\subsubsection{RCM of PCK}

The model is made up of enacted PCK (ePCK), personal PCK (pPCK), learning context, collective PCK (cPCK), and professional knowledge bases (Carlson \& Daehler, 2019). By the use of concentric circles and two-way knowledge exchange arrows, the RCM makes all of the attributes and types of PCK explicit on one hand and represents their complicated relationships on the other hand. The design of the model (Figure 1) conveys information on several considerations of PCK. First of all, it promotes the central placement of PCK visible among other professional knowledge bases that emphasizes the transformative views on PCK (Tepner \& Sumfleth, 2019). Second, it reinforces the value of science teaching practice in a specific setting for a particular student through the central placement of ePCK, which further means that the RCM of PCK orients practitioner perspective. Third, it intends to visualize transformations that can occur among each component of the model through amplifiers and/or filters (e.g., teacher beliefs) without referencing those amplifiers and/or filters on the graphic representation of the RCM of PCK itself. Lastly, the model depicts the dynamic nature of ePCK through the whole pedagogical cycle of instruction.

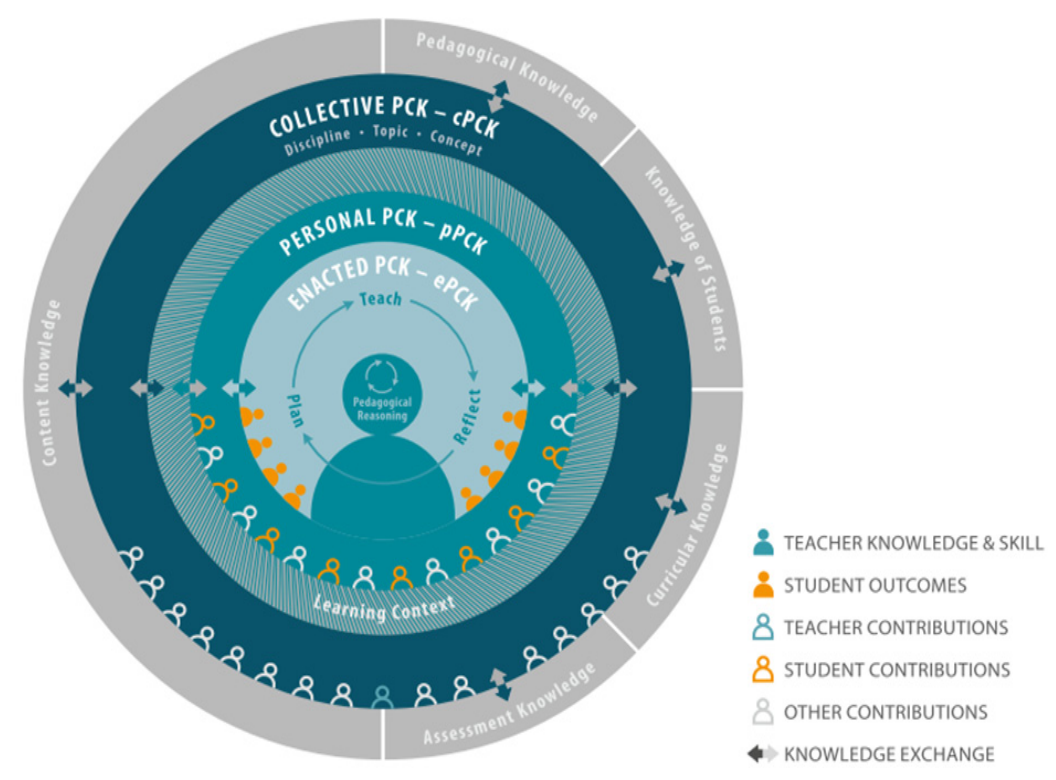

Figure 1. Graphical representation of the RCM of PCK (Carlson \& Daehler, 2019, p. 83) 
The major contribution of RCM of PCK to literature is the introduction of three variants of PCK: cPCK, pPCK, and ePCK. The reason why this distinction is of importance lies in the answer to the following question; what does each form of PCK represent? They have somewhat common features, like all forms of PCK may have a multidimensional nature in terms of grain size (i.e., discipline-specific to topic-specific to concept-specific) (Mavhunga, 2019) and some distinct features, such as while pPCK and ePCK (being the most) depend firmly on the learning context, $\mathrm{cPCK}$ is generalizable to some extent; cPCK represents a more canonical knowledge of science but pPCK and ePCK represent personalized professional knowledge and skills (Carlson \& Daehler, 2019).

The interior circle of the RCM belongs to ePCK which represents how teachers make use of their specific knowledge and skills throughout the planning, enacting, and reflecting phases of instruction. If one plans to investigate how teachers apply their knowledge in the practice of science teaching when reflecting on action (the acts of planning for and reflecting on teaching tasks) and reflecting in action (the actual act of teaching) (Park \& Oliver, 2008), he/she should focus on ePCK (Carlson \& Daehler, 2019; Chan \& Hume, 2019). Consistent with the RCM of PCK, ePCK was defined operationally as the flexible knowledge and skills that a science teacher uses in the midst of $o n$ action and in action.

\subsection{Significance of This Research}

Before turning attention to the particular research efforts on how the $\mathrm{RCM}$ framed this research while conceptualizing, investigating, and interpreting the findings, it is important to underlie what ePCK involves. Although he did not name it as ePCK, Shulman's (2015) recent operationalization of PCK made it apparent that it is not a static knowledge that an individual teacher brings to all settings but "a more dynamic construct that described the processes that teachers employed when confronted with the challenge of teaching particular subjects to particular learners in particular settings" (p. 9). This research investigates teachers' ePCK by referring to what it means in the RCM that is consistent also with the recent PCK definition of Shulman (2015). Besides to importance of investigating the type of PCK that is related directly to science teaching practice based on the RCM (i.e., ePCK), this research hopes to contribute to PCK literature in another way. Even though the RCM is a reflection of collective and updated thoughts of leading scholars, the model and the suggested perspectives (e.g., measurement of distinct forms of PCK by the grand rubric) need to be tested in terms of its utility in research (Carlson \& Daehler, 2019). In short, it is an expected value of this research to further the literature by taking a step upon the most recent consensual views on PCK.

This study search for ePCK profiles of chemistry teachers throughout the whole pedagogical cycle by conceptualizing ePCK to "exist in three forms: ePCK for planning (ePCK $)$, ePCK for teaching $\left(\mathrm{ePCK}_{\mathrm{T}}\right)$ and ePCK for reflecting $\left(\mathrm{ePCK}_{\mathrm{R}}\right)$ " (Alonzo et al., 2019, p. 272). This holistic conceptualization of ePCK can be interpreted as science teachers' ePCK profile for planning may not necessarily reflect his/her profile for teaching or reflecting which is also valid for other possible comparisons of ePCK phases. That interpretation was reported as one of the issues related to how researchers investigate PCK by Chan \& Hume (2019), as well, in 
which they have concluded that "studies often generated a single profile of a science teacher's PCK rather than providing a finer distinction between the PCK associated with different phases of the teaching cycle" (p. 53).

In their study, Chan and Hume (2019) figured out two approaches for investigating science teachers' cPCK, pPCK, and ePCK where the first approach was suggested for determining what teachers know, and the second one for eliciting what teachers do while preparing teaching tasks and engaging directly with students. That second approach, performance in teaching tasks, was outlined especially for ePCK which includes teachers' procedural knowledge (knowing how) and strategic knowledge (knowledge of when, where, and how knowledge applies) according to Shavelson, Ruiz-Primo, and Wiley (2005)'s forms of knowledge for teaching and learning (as cited in Chan \& Hume, 2019). Together with research methods, Chan and Hume (2019) classified various data collection sources that fit well with those approaches. Additionally, given that ePCK is utilized not only when teaching but also when planning and reflecting (Carlson \& Daehler, 2019), multiple data sources should be used while eliciting different phases of instruction (Park, 2019). Consistent with the above methodological approach which aligns well with the RCM of PCK, this research portrayed chemistry teachers' ePCK through performance in teaching tasks by using multiple data sources throughout the overall pedagogical cycle in real-life contexts.

It can be readily acknowledged that the findings were interpreted concerning the RCM of PCK as it framed this research both conceptually (e.g., the multidimensional nature of ePCK) and methodologically (e.g., the approach for eliciting ePCK profiles). Specifically, all decisions about research attempts were made in a manner to inform each other through which genuine alignment to the RCM of PCK was expected to be achieved. For example, a rubric template that is built on the RCM (Chan et al., 2019) was customized for portraying chemistry teachers' ePCK by deciding on the components of ePCK along with the ePCK-related quality indicators that well-align with the RCM. That rubric allows researchers to analyze PCK with different science content and grain sizes. By the use of this tool for eliciting chemistry teachers' ePCK, this study gained novelty in certain aspects. First, it provided completeness with the framework as "it is built on the RCM" (p. 267). Second, it enabled valid assessment hence it draws on best practices and considerations of experts in the field of science PCK. Third, it ensured a reliable means for measuring ePCK. This issue is especially important because ePCK is a new construct in the field and scholars ask for reliable and valid tools to analyze ePCK (e.g., Park, 2019) as most of the existing rubrics are suitable for measuring static PCK (Chan et al., 2019), like pPCK. Finally, it proposes components of ePCK though the RCM of PCK did not devote itself to do so.

Collectively, the purpose of this research is to portray chemistry teachers' ePCK in equilibrium in chemical reactions throughout the whole pedagogical cycle. The research question is "what are the ePCK profiles of chemistry teachers in equilibrium in chemical reactions?" 


\section{Method}

\subsection{Research Design}

The essences of the RCM of PCK were carried out to this research context through survey research that describes certain characteristics of a group (Büyüköztürk, Kılıç-Çakmak, Akgün, Karadeniz, \& Demirel, 2010) through counts of frequency mostly. Survey research is utilized in this research to collect data about chemistry teachers' ePCK profiles in equilibrium in chemical reactions.

\subsection{Participants}

The more the number of participants to be investigated, the more this research contributes to the rigor representation of chemistry teachers' ePCK profiles. Thus, an effort has been devoted toward a study that has a relatively higher sample size than previously conducted qualitative studies in the field. To that aim, all teachers, who teach chemistry to grade 11 students (aged 17-18) (as the particular concept of interest is to be taught in that grade) in a small city locates in the Mediterranean region of Turkey, have been informed on the details of this research. Of them, volunteered 45 chemistry teachers over two career stages changing from the beginning (less than five years of experience) to experienced (more than five years of experience) involved as a working group. All teachers follow the same curriculum materials while teaching chemistry regardless of the type of school they are working in. Table 1 introduces details of information on participating teachers' background and context for their chemistry teaching experience.

Table 1. Background and contextual information of the participants

\begin{tabular}{|c|c|c|c|c|c|c|c|}
\hline \multirow{2}{*}{$\begin{array}{l}\text { Chemistry teaching } \\
\text { experience }\end{array}$} & \multicolumn{2}{|c|}{ Gender } & \multicolumn{2}{|c|}{ Education } & \multicolumn{2}{|c|}{ School context } & \multirow{2}{*}{ Total } \\
\hline & Female & Male & Undergraduate degree & Master degree & State school & Private school & \\
\hline Beginning & 18 & 2 & 11 & 9 & 13 & 7 & 20 \\
\hline Experienced & 22 & 3 & 23 & 2 & 22 & 3 & 25 \\
\hline Total & 40 & 5 & 34 & 11 & 35 & 10 & 45 \\
\hline
\end{tabular}

\subsection{Data Collection}

Multidimensionality of ePCK was investigated by the second approach proposed by Chan and Hume (2019), i.e., performance in teaching tasks, throughout the overall pedagogical cycle in real-life contexts. Given that ePCK is utilized while planning, teaching, and reflecting (Carlson \& Daehler, 2019), multiple data sources were used as suggested by the literature (e.g., Park, 2019). Specifically, pre-and post-observation interviews and lesson observations were used to elicit chemistry teachers' ePCK profiles. By the use of multiple sources and by searching for consistent evidence among data during analysis, triangulation of methods and sources are to be ensured that makes the findings of this research more credible 
(Creswell, 2009).

\subsubsection{Pre- and Post-Observation Interviews}

Interviews were semi-structured and conducted face-to-face before and after lesson observations. While the former was carried out to probe into teachers' planning decisions for the lesson they were to teach that provided data mainly for $\mathrm{PCK}_{\mathrm{P}}$, the latter was used to investigate consistency between the planned and the enacted lessons they taught that ensured data specifically for $\mathrm{ePCK}_{\mathrm{R}}$. An interview protocol involving the first three ePCK components of the grand rubric (GR) - curricular saliency, conceptual teaching strategies, and student understanding of science-was prepared. Interview questions were prepared based on quality indicators of these ePCK components. Table 2 shows samples to interview questions. Follow-up questions were asked as well to ensure information about the learning context and/or to clarify the underlying reasons of teachers' pedagogical moves and/or to make teachers further reflect on critical incidents that occurred while they were teaching (Merriam, 2009). As evidence of consistency was searched among interview and follow-up questions, it can be argued that triangulation of sources is to be ensured (Patton, 2002) by interviews.

Though pre-observation interviews took place in the same week with lesson observations, post-observation interviews were conducted two weeks after lesson observations due to the necessity of organizing a considerable amount of video recordings of observations. The researcher watched each participating teachers' video-recorded lessons and edited the post-observation interview protocol accordingly. Each interview took about half an hour for pre-and an hour for post-observation interviews. All of the interviews were audio-recorded and transcribed verbatim.

Table 2. Sample pre- and post-observation interview questions

\begin{tabular}{|l|l|}
\hline Pre-observation interview questions & Post-observation interview questions \\
\hline $\begin{array}{l}\text { What is the planned content of equilibrium } \\
\text { in chemical reactions lessons? How did you } \\
\text { decide on this content? }\end{array}$ & $\begin{array}{l}-\quad \text { Can you give sample instances of inconsistency between the } \\
\text { planned and the enacted content, if any? } \\
\text { - Will you change the content of equilibrium in chemical } \\
\text { reactions lessons in future planning and enactments? }\end{array}$ \\
\hline $\begin{array}{l}\text { planned for facilitating student understanding of } \\
\text { the equilibrium in chemical reactions concepts? }\end{array}$ & $\begin{array}{l}-\quad \text { Can you give sample instances of inconsistency between the } \\
\text { selected and the used instructional strategies, if any? }\end{array}$ \\
& $\begin{array}{l}\text { Is there a difference for future planning and enactments in } \\
\text { terms of instructional strategies? }\end{array}$ \\
\hline
\end{tabular}

\subsubsection{Lesson Observations}

Being one of the self-report approaches (Chan \& Hume, 2019), interviews solely cannot provide enough information about what and how teachers use their knowledge and skills 
during the actual practices of teaching (Patton, 2002). On the contrary, an approach that utilizes pre- and post-observation interviews in conjunction with lesson observations is more effective (Carlson et al., 2019) when the purpose of research is to portray ePCK. The primary reason for collecting data through lesson observations then, to collect data for $\mathrm{ePCK}_{\mathrm{T}}$.

Similar to the rationale of asking follow-up questions during interviews, observations were utilized to collect additional data on contextual information, pedagogical moves of teachers, and special events that occurred in the classroom (Merriam, 2009). By comparing findings in terms of consistency among interviews and observations, methods triangulation is to be achieved (Patton, 2002).

Non-participant observations were preferred (Gray, 2014) and observations were video recorded instead. The reason why the researcher did not take the announced participant role was that all of the participants taught the equilibrium in chemical reactions topic at the same week according to the national curriculum they follow up. Video-recorded observations have several advantages over the participant observations, such as having a chance of watching the video several times while analyzing data and reducing the anxiety that may occur while researchers take field notes (Gray, 2014). Consistent with the curriculum schedule, each participating teacher allocated three lesson hours for teaching the topic, one of which is 40 minutes long. 135 lesson hours (i.e., 5400 minutes) were video-recorded to be analyzed in this research.

\subsection{Data Analysis}

Numerous researchers have used rubrics for measuring PCK within the science education literature (e.g., Carpendale \& Hume, 2019; Mavhunga \& Rollnick, 2013; Park et al., 2011). In that vein, data drawn from this research were analyzed by a rubric, which is the grand contribution of Chan et al. (2019) to the science PCK community. The proposed GR template is composed of five ePCK components, namely "knowledge and skills related to curricular saliency, knowledge, and skills related to conceptual teaching strategies, knowledge, and skills related to student understanding of science, integration between PCK components, and pedagogical reasoning" (p. 264). The reason why GR involves integration between PCK components and pedagogical reasoning as part of PCK may be related to the importance given to both terms in the science PCK literature in general and in the RCM of PCK in particular. However, it is not as clear as the first three components that how to measure integration between PCK components and pedagogical reasoning by GR. Moreover, investigating the interaction between components of PCK and teachers' pedagogical reasoning is out of the scope of this research which instead aims to investigate ePCK profiles of chemistry teachers throughout the whole pedagogical cycle. As a result, GR was customized around the analytical parameters of knowledge and skills related to curricular saliency (CS), conceptual teaching strategies (CTS), and student understanding of science (SUS).

Evaluation criteria for these components were derived from Chan et al. (2019) with slight modifications. Specifically, those were grouped according to their relevance in such a way to have the same number of evaluation criteria for each ePCK component. In other words, an 
analytical rubric was created in which each of the CS, CTS, and SUS components were represented by two criteria and hence, contribute the same to participants' ePCK profiles. The final evaluation criteria were as follows: "content and big ideas" for CS; "instructional strategies and representations" for CTS; "variations in student learning and student difficulty" for SUS.

Chan et al. (2019) did not share quality indicators to allow researchers to form rubrics suitable for their settings and research purposes. Therefore, this broad template was customized by assigning quality indicators across performance levels for CS, CTS, and SUS for measuring ePCK (Appendix A). Performance levels were determined as "not applicable (0), basic (1), developing (2) and exemplary (3)", as used by Mavhunga and Rollnick (2013) with a minor revision, that is, "not applicable" instead of "limited" level. The reason why a limited level was not preferred is to avoid possible confusion between no knowledge and skills (i.e., not applicable) and little knowledge and skills (i.e., limited) (Park et al., 2018). Overall, all sorts of data were analyzed by the customized GR to portray chemistry teachers' ePCK in equilibrium in chemical reactions throughout the whole pedagogical cycle. Table 3 indicates sample data analysis for "representations" criteria of CTS components across each phase of the pedagogical cycle. For saving their confidentiality, teachers were coded from 1 to 45 .

Table 3. Sample data analysis for "representations" criteria of CTS component

\begin{tabular}{|c|c|c|c|}
\hline & Data collection & Sample excerpts and Researcher notes & $\begin{array}{l}\text { Assigned level } \\
\text { of performance }\end{array}$ \\
\hline Planning & $\begin{array}{l}\text { Pre-observation interview question } \\
\text { - Which representations do you } \\
\text { think help students learn } \\
\text { equilibrium in chemical reaction } \\
\text { concepts easier? }\end{array}$ & $\begin{array}{l}\text { T25* "most of the students have trouble with the meaning of } \\
\text { dynamic equilibrium concept. To make the concept easier for } \\
\text { them [students] we [teachers] can use analogies, physical } \\
\text { models, animations, diagrams, etc. In one of my classes, } \\
\text { students role-played regarding forward and backward } \\
\text { reactions". }\end{array}$ & Exemplary (3) \\
\hline Teaching & $\begin{array}{l}\text { Lesson observation } \\
\text { - Does the teacher attempt to use } \\
\text { multiple representations? } \\
\text { - Does the teacher link use } \\
\text { representations to equilibrium in } \\
\text { chemical reaction concepts? }\end{array}$ & $\begin{array}{l}\text { T33* started the lesson by saying "in our red blood cells, a } \\
\text { protein called hemoglobin reacts with oxygen". Students } \\
\text { wonder about the lesson after this daily life example. Video, } \\
\text { symbols, formulas were used frequently. T33 finalized the } \\
\text { lesson by introducing a simulation showing a stable } \\
\text { concentration of reactants and products at the dynamic } \\
\text { equilibrium point. }\end{array}$ & Exemplary (3) \\
\hline Reflecting & $\begin{array}{l}\text { Post-observation interview question } \\
\text { - Can you give sample instances } \\
\text { of inconsistency between the } \\
\text { specified and the used } \\
\text { representations, if any? } \\
\text { - Is there a difference between } \\
\text { future planning and enactments in } \\
\text { terms of representations? }\end{array}$ & $\begin{array}{l}\mathrm{T} 7 * \text { "though I planned to use technology-supported activities, } \\
\text { I could not... due to technical problems. I will check for every } \\
\text { circumstance before lessons ... for coming [future lessons]. } \\
\text { On the contrary, they [students] prepared a poster within small } \\
\text { groups about rates of forwarding and backward reactions and } \\
\text { concentrations of reactants and products at the equilibrium } \\
\text { point. This is actually what I have planned". }\end{array}$ & Basic (1) \\
\hline
\end{tabular}

Note. ${ }^{*}$ T25 stands for the teacher who coded as 25; T33 stands for the teacher who coded as 33; T7 stands for the teacher who coded as 7. 
A scoring rubric (Appendix B) was developed as well based on the reality that a chemistry teacher attains a maximum of 18 and a minimum of zero points concerning $\mathrm{ePCK}_{\mathrm{P}}, \mathrm{ePCK}_{\mathrm{T}}$, and $\mathrm{ePCK}_{\mathrm{R}}$. More specifically, chemistry teachers were assigned to "not applicable" level for each ePCK profiles if they take zero points on each of the evaluation criteria of CS, CTS, and SUS; to "basic" level for each ePCK profiles if they take points between 1 and 6 on each of the evaluation criteria of CS, CTS and SUS; to "developing" level for each ePCK profiles if they take points between 7 and 12 on each of the evaluation criteria of CS, CTS, and SUS; to "exemplary" level for each ePCK profiles if they take points between 13 and 18 on each of the evaluation criteria of CS, CTS, and SUS. Data taken from the scoring rubric were used to qualitatively label teachers' ePCK profiles instead of using those for quantitative purposes.

\section{Results}

ePCK profiles of chemistry teachers in teaching equilibrium in chemical reactions were reported below by referencing mainly to Table 4 which introduces the number of teachers in each level of performance for phases of the pedagogical cycle, ePCK components, and evaluation criteria.

Table 4. Number of teachers in each ePCK profiles

\begin{tabular}{|l|l|l|l|l|l|l|l|}
\hline \multirow{2}{*}{ ePCK Components } & \multicolumn{2}{|c|}{ CS } & \multicolumn{2}{c|}{ CTS } & \multicolumn{3}{c|}{ SUS } \\
\hline \multirow{2}{*}{ Evaluation Criteria* } & Con. & BI & IS.s & Repr.s & Var.s & SD \\
\hline \multirow{3}{*}{ PCK $_{\mathrm{P}}$} & Basic & 13 & 12 & 2 & 10 & 10 & 11 \\
\cline { 2 - 9 } & Developing & 25 & 24 & 11 & 15 & 24 & 25 \\
\cline { 2 - 9 } & Exemplary & 7 & 9 & 32 & 20 & 11 & 9 \\
\hline \multirow{5}{*}{ PCK $_{\mathrm{T}}$} & Basic & 20 & 22 & 24 & 17 & 18 & 17 \\
\cline { 2 - 9 } & Developing & 19 & 14 & 16 & 24 & 25 & 25 \\
\cline { 2 - 9 } & Exemplary & 6 & 9 & 5 & 4 & 2 & 3 \\
\hline \multirow{5}{*}{$\mathrm{PCK}_{\mathrm{R}}$} & Basic & 6 & 8 & 5 & 4 & 24 & 30 \\
\cline { 2 - 9 } & Developing & 16 & 21 & 12 & 14 & 16 & 9 \\
\cline { 2 - 8 } & Exemplary & 23 & 16 & 28 & 27 & 5 & 6 \\
\hline
\end{tabular}

Note. *Con.: content; BI: big ideas; IS.s: instructional strategies; Repr.s: representations; Var.s: variations in student learning; SD: student difficulty.

Any teachers were having "not applicable" ePCK profiles. The most and the least owned ePCK profiles in planning (i.e., $\mathrm{ePCK}_{\mathrm{P}}$ ), teaching (i.e., $\mathrm{ePCK}_{\mathrm{T}}$ ) and reflection (i.e., $\mathrm{ePCK}_{\mathrm{R}}$ ) were as follow: "developing" (the most) and "basic" (the least); "developing" and "exemplary"; "exemplary" and "basic", respectively. Since teachers having "exemplary" profile gain greater points (i.e., three points) than "developing" (i.e., two points) and "basic" profiles (i.e., one point) (Appendix A), the above result can be reported as teachers' $\mathrm{PCK}_{\mathrm{R}}$ 
profiles are more qualified than $\mathrm{ePCK}_{\mathrm{P}}$ and $\mathrm{ePCK}_{\mathrm{T}}$ profiles, and their $\mathrm{ePCK}_{\mathrm{P}}$ profiles are more qualified than $\mathrm{ePCK}_{\mathrm{T}}$ profiles. Besides approving the above trend, Figure 2 shows a dramatic decrease in teachers' performance in the teaching phase and a sharp increase in their performance in the reflection phase, as well.

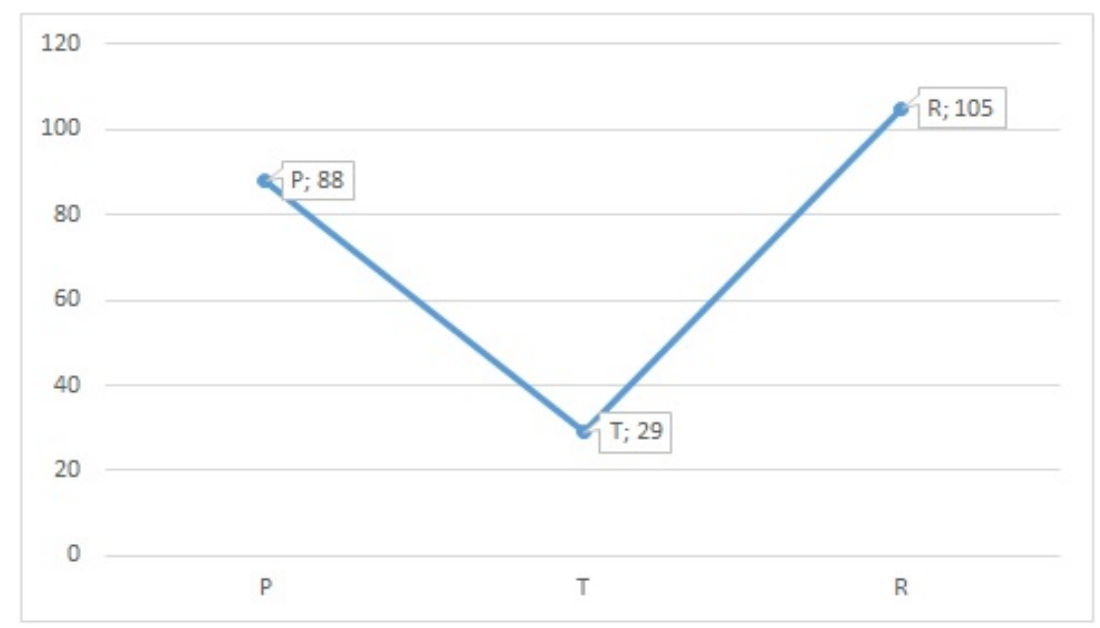

Figure 2. Number of teachers in "exemplary" profile across phases of the pedagogical cycle

Along with $\mathrm{ePCK}_{\mathrm{P}}, \mathrm{ePCK}_{\mathrm{T}}$, ePCK $\mathrm{R}$ profiles mark variations in the CS component, it can be said that teachers' have the highest performance in reflection concerning CS since "exemplary" is the most owned profile in that phase. When the difference between the number of teachers who owned "exemplary" and "basic" profiles for CS are examined, one sees that $\mathrm{ePCK}_{\mathrm{R}}(25)$ favors "exemplary" but $\mathrm{ePCK}_{\mathrm{P}}$ and $\mathrm{ePCK}_{\mathrm{T}}$ (9 and 27, respectively) favor "basic" profile. This result not only approves teachers' best quality in the reflection in CS component but also reveals their better quality in planning than the teaching phase. Looking at the number of teachers who owned "exemplary" profiles in CS across phases indicates teachers' deep performance rise after teaching.

Though the most owned profile is "exemplary" in $\mathrm{ePCK}_{\mathrm{P}}$ and $\mathrm{ePCK}_{\mathrm{R}}$ concerning CTS, "basic" is the most owned profile in $\mathrm{ePCK}_{\mathrm{T}}$. Therefore, teachers' have the lowest performance in teaching CTS. To find out the relationship between planning and reflection, the difference between the number of teachers who owned "exemplary" and "basic" profiles for CTS and/or the number of teachers who owned "exemplary" profiles in CTS across planning and reflection can be investigated. Both the former (40 teachers in planning and 46 teachers in reflection) and the latter (52 teachers in planning and 55 teachers in reflection) investigation detect a slightly more performance in $\mathrm{ePCK}_{\mathrm{R}}$ than $\mathrm{ePCK}_{\mathrm{P}}$. These results make appear teachers' performance raise after teaching in terms of CTS, meanwhile. Another point of view can be developed through analyzing all ePCK components across phases in terms of the profile owned most by teachers. This analysis reveals that teachers perform better in planning for CTS than CS and SUS. 


\section{Al Macrothink}

Journal of Educational Issues

ISSN 2377-2263

2021, Vol. 7, No. 1

Though the most owned profile is "developing" in $\mathrm{ePCK}_{\mathrm{P}}$ and $\mathrm{ePCK}_{\mathrm{T}}$ concerning SUS, "basic" is the most owned profile in $\mathrm{ePCK}_{\mathrm{R}}$. Correspondingly, teachers' have the lowest performance in reflecting about SUS. Any teachers' having most of the "exemplary" ePCK profile in any phases concerning SUS is a striking result which results in making comparisons of the difference between the number of teachers who owned "developing" and "basic" profiles for $\mathrm{ePCK}_{\mathrm{P}}$ and $\mathrm{ePCK}_{\mathrm{T}}$ related results. That difference favors the "developing" profile for both $\mathrm{ePCK}_{\mathrm{P}}$ and $\mathrm{ePCK}_{\mathrm{T}}$ (28 and 15, respectively). In that case, it can be reported that teachers perform better in planning than the teaching phase and they undergo a dramatic decrease in their performance after the teaching phase in terms of SUS. View of analyzing all ePCK components across phases in terms of the profile owned most by teachers reveals that teachers perform higher in teaching and perform lower in reflecting for SUS than CS and CTS.

Teachers have the same $\mathrm{ePCK}_{\mathrm{P}}$ profiles in terms of the number they owned the most and the least for CS and CTS criteria, that is, "developing" is the most for Con. and BI and "exemplary" is the most for IS.s and Rep.s; "exemplary" is the least for Con. and BI and "basic" is the least for IS.s and Rep.s. For SUS criteria, on the contrary, teachers' ePCK $_{P}$ profile in terms of the number they owned the most is the same but the number they owned the least are distinct. Specifics of this variation are that "developing" is the most for both Var.s and SD; "basic" is the least for Var.s but "exemplary" is the least for SD.

Teachers have the same ePCK $\mathrm{T}$ profiles in terms of the number they owned the most and the least for CS and SUS criteria, that is, "basic" is the most for Con. and BI and "developing" is the most for Var.s and SD; "exemplary" is the least for Con., BI, Var.s and SD. For CTS criteria, on the contrary, teachers' $\mathrm{ePCK}_{\mathrm{T}}$ profile in terms of the number they owned the least is the same but the number they owned the most is distinct. Specifics of this variation are that "exemplary" is the least for IS.s and Rep.s; "basic" is the most for IS.s but "developing" is the most for Rep.s.

Teachers have the same ePCK $\mathrm{R}_{\mathrm{R}}$ profiles in terms of the number they owned the most and the least for CTS and SUS criteria, that is, "exemplary" is the most for IS.s and Rep.s and "basic" is the most for Var.s and SD; "basic" is the least for IS.s and Rep.s and "exemplary" is the least for Var.s and SD. For CS criteria, on the contrary, teachers' $\mathrm{ePCK}_{\mathrm{R}}$ profile in terms of the number they owned the least is the same but the number they owned the most is different. Specifically, "basic" is the least for Con. and BI; "exemplary" is the most for Con. but "developing" is the most for BI.

\section{Discussion}

The purpose of this research is to portray chemistry teachers' ePCK in equilibrium in chemical reactions throughout the whole pedagogical cycle. To attain this purpose, ePCK was conceptualized as to exist in three forms namely, ePCK, $\mathrm{ePCK}_{\mathrm{T}}$, and $\mathrm{ePCK}_{\mathrm{R}}$ (Alonzo et al., 2019, p. 272). All of these ePCK profiles were analyzed around Con., BI, IS.s, Rep.s, Var.s, and SD criteria of CS, CTS, and SUS components of ePCK.

The complete picture of chemistry teachers' ePCK profiles can be portrayed by combining 
results related to phases, components, and evaluation criteria. From the most qualified to the least one, this combination can be concluded as in Figure 3 (below subscripts show phases, components, and evaluation criteria, respectively).

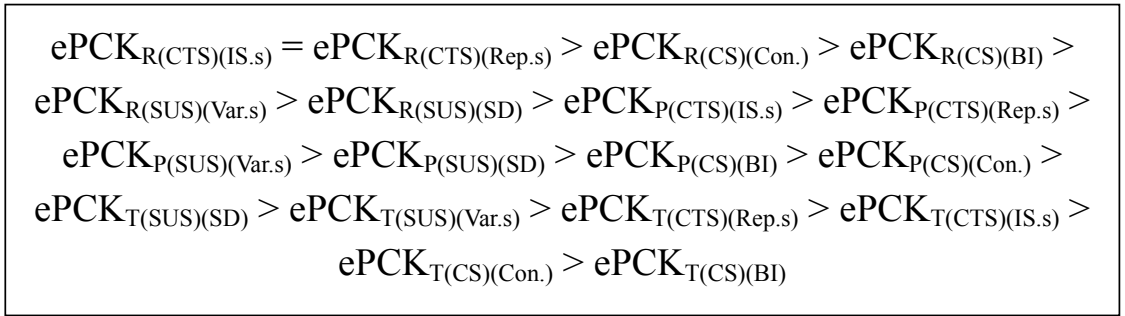

Figure 3. Chemistry teachers' ePCK profiles in equilibrium in chemical reactions

The above figure reveals two main trends to be discussed. Firstly, chemistry teachers' ePCK profiles are not uniform, that is, a teacher's ePCK profile may show variations for planning, teaching, and reflecting phases. This trend supports Chan and Hume (2019) who reported that "studies often generated a single profile of a science teacher's PCK rather than providing a finer distinction between the PCK associated with different phases of the teaching cycle" ( $p$. 53). Although a teacher has exemplary knowledge and skills of consistency between the selected and the used instructional strategies that facilitate students' understanding of equilibrium in chemical reactions concepts, he/she may not have the same level of performance in his/her skills of making the content of the equilibrium in chemical reactions lesson common for students to learn. Alternatively, a teacher who cannot well-aligned the content of the equilibrium in chemical reactions lessons accurately relative to the goals of the $11^{\text {th }}$-grade curriculum with a sound understanding of the pedagogical value of the curriculum may recognize necessary changes for future planning after he/she taught that lesson.

Secondly, chemistry teachers' performance level shows a striking increase after the teaching phase excluding SUS component. The reason of rising in CS and CTS components of ePCK can be interpreted as teachers realize the difference between planning and teaching contexts. In other words, teachers may learn to reflect on action after reflecting in action (Park \& Oliver, 2008). The actual act of teaching may play an intervention role for teachers' future planning and enactments in terms of CS and CTS components of ePCK. As teachers experience teaching, they learn more about a sound understanding of the pedagogical value of the curriculum, making the content common for students to learn, selecting core concepts of the equilibrium in chemical reactions to teaching, connecting core concepts across the horizontal and vertical curriculum, managing time to spend on core concepts, selecting and using appropriate and accurate instructional strategies and using multiple representations to facilitate student understanding of the equilibrium in chemical reactions concepts. This trend of CS and CTS corresponds exactly how ePCK is conceptualized, which is the flexible knowledge and skills that a science teacher uses in on action and in action (Carlson \& Daehler, 2019). 
SUS-related knowledge and skills, on the other hand, indicate more static features in this research. Specifically, what teachers know about students' developmental levels, ability levels, learning styles, interests, skills (Magnusson, Krajcik, \& Borko, 1999) to understand the equilibrium in chemical reactions concepts and the attempts to respond to them are rather stable. Furthermore, teachers' knowledge and skills of reasons of student difficulty in understanding the equilibrium in chemical reactions concepts that include; aspect(s) of the concepts students find abstract and/or inaccessible to their common experiences, kind(s) of common errors in students' reasoning, misconception(s) students may have about the concepts (Magnusson et al., 1999) and the ways to respond to them are more resistant to be improved even teaching experiences. In that vein, SUS can be treated as a personal PCK component instead of ePCK component.

Although PCK literature in science education has studies explaining distinct types of PCK (e.g., Carlson \& Daehler, 2019; Chan \& Hume, 2019; Park, 2019; Park \& Suh, 2019) and those investigating PCK types (e.g., Akinyemi \& Mavhunga, 2020; Alonzo et al., 2019; Carpendale \& Hume, 2019; Mavhunga, 2019; Vollebregt, Gaigher, \& Coetzee, 2021), more study is required to understand what is there at the center of the concentric circles, which is a rather recent conceptualization of PCK. A review of the place of SUS component (i.e., whether an ePCK component) can be recommended in future investigations.

\section{References}

AAAS (American Association for the Advancement of Science). (1993). Benchmarks for Science Literacy: A Project 2061 Report. New York: Oxford University Press.

Abell, S. K. (2007). Research on science teacher knowledge. In S. K. Abell \& N. G. Lederman (Eds.), Handbook of research on science education (pp. 1105-1149). Mahwah: Lawrence Earlbaum Associates.

Abell, S. K. (2008). Twenty years later: Does pedagogical content knowledge remain a useful idea? International Journal of Science Education, 30(10), 1405-1416. https://doi.org/ $10.1080 / 09500690802187041$

Akinyemi, O. S., \& Mavhunga, E. (2021). Linking pre-service teachers' enacted topic-specific pedagogical content knowledge to learner achievement in organic chemistry. Chemistry Education Research and Practice, 22, 282-302. https://doi.org/10.1039/D0RP 00285B

Alonzo, A. C., Berry, A., \& Nilsson, P. (2019). Unpacking the Complexity of Science Teachers' PCK in Action: Enacted and Personal PCK. In A. Hume, R. Cooper, \& A. Borowski (Eds.), Repositioning pedagogical content knowledge in teachers' knowledge for teaching science (pp. 271-286). Singapore, Springer. https://doi.org/10.1007/978-981-135898-2_12

Büyüköztürk, Ş., Kılıç-Çakmak, E., Akgün, Ö. E., Karadeniz, Ş., \& Demirel, F. (2010). Bilimsel araştırma yöntemleri (5th ed.). Ankara: Pegem Akademi.

Carlson, J., \& Daehler, K. R. (2019). The refined consensus model of pedagogical content 
knowledge in science education. In A. Hume, R. Cooper, \& A. Borowski (Eds.), Repositioning pedagogical content knowledge in teachers' knowledge for teaching science (pp. 77-92). Singapore: Springer.

Carlson, J., Cooper, R., Daehler, K. R., Friedrichsen, P. J., Heller, J. I., Kirschner, S., ... Wong, N. (2019). Vignettes illustrating practitioners' and researchers' applications of the refined consensus model of pedagogical content knowledge. In A. Hume, R. Cooper, \& A. Borowski (Eds.), Repositioning pedagogical content knowledge in teachers' knowledge for teaching science (pp. 77-92). Singapore: Springer. https://doi.org/10.1007/978-981-135898-2_3

Carpandale, J., \& Hume, A. (2019). Investigating practicing science teachers' pPCK and ePCK development as a result of the collaborative CoRe design. In A. Hume, R. Cooper, \& A. Borowski (Eds.), Repositioning pedagogical content knowledge in teachers' knowledge for teaching science (pp. 223-250). Singapore, Springer. https://doi.org/10.1007/978-981-135898-2_10

Chan, K. K. H., \& Hume, A. (2019). Towards a consensus model: Literature review of how science teachers' pedagogical content knowledge is investigated in empirical studies. In A. Hume, R. Cooper, \& A. Borowski (Eds.), Repositioning pedagogical content knowledge in teachers' knowledge for teaching science (pp. 3-76). Singapore, Springer. https://doi.org/ 10.1007/978-981-13-5898-2_1

Chan, K. K. H., Rollnick, M., \& Gess-Newsome, J. (2019). A grand rubric for measuring science teachers' pedagogical content knowledge. In A. Hume, R. Cooper, \& A. Borowski (Eds.), Repositioning pedagogical content knowledge in teachers' knowledge for teaching science (pp. 251-269). Singapore, Springer. https://doi.org/10.1007/978-981-13-5898-2_11

Creswell, J. W. (2009). Research design: Qualitative, quantitative and mixed-method apdoing proaches (3rd ed.). Sage Publications.

Gray, D. E. (2014). Doing research in the real world (3rd ed.). Sage Publications.

Hume, A., Cooper, R., \& Borowski, A. (2019). Repositioning pedagogical content knowledge in teachers' knowledge for teaching science. Singapore: Springer. https://doi.org/10.1007/ 978-981-13-5898-2

Kind, V., \& Chan, K. K. H. (2019). Resolving the amalgam: Connecting pedagogical content knowledge, content knowledge, and pedagogical knowledge. International Journal of Science Education, 41(7), 964-978. https://doi.org/10.1080/09500693.2019.1584931

Magnusson, S., Krajcik, J., \& Borko, H. (1999). Nature, sources and development of pedagogical content knowledge for science teaching. In J. Gess-Newsome \& N. G. Lederman (Eds.), Examining pedagogical content knowledge: The construct and its implications for science education (pp. 95-132). Boston, MA: Kluwer. https://doi.org/10.1007/0-30647217-1_4

Mavhunga, E. (2019). Exposing pathways for developing teacher pedagogical content 
knowledge at the topic level in science. In A. Hume, R. Cooper \& A. Borowski (Eds.), Repositioning pedagogical content knowledge in teachers' knowledge for teaching science (pp. 129-148). Singapore, Springer. https://doi.org/10.1007/978-981-13-5898-2_5

Mavhunga, E., \& Rollnick, M. (2013). Improving PCK of chemical equilibrium in pre-service teachers. African Journal of Research in Mathematics, Science and Technology Education, 17(1), 113-125. https://doi.org/10.1080/10288457.2013.828406

Merriam, S. B. (2009). Qualitative research: A guide to design and implementation: Revised and expanded from qualitative research and case study applications in education. San Francissco Jossey-Boss.

NRC (National Research Council). (1996). National Science Education Standards. Washington, DC: National Academy Press.

Park, S. (2019). Reconciliation between the refined consensus model of PCK and extant PCK models for advancing PCK research in science. In A. Hume, R. Cooper, \& A. Borowski (Eds.), Repositioning pedagogical content knowledge in teachers' knowledge for teaching science (pp. 185-197). Singapore, Springer. https://doi.org/10.1007/978-981-13-5898-2_4

Park, S., \& Oliver, J. S. (2008). Revisiting the conceptualization of pedagogical content knowledge (PCK): PCK as a conceptual tool to understand teachers as professionals. Research in Science Education, 38, 261-284. https://doi.org/10.1007/s11165-007-9049-6

Park, S., \& Suh, J. K. (2019). The PCK Map Approach to Capturing the Complexity of Enacted PCK (ePCK) and Pedagogical Reasoning in Science Teaching. In A. Hume, R. Cooper \& A. Borowski (Eds.), Repositioning pedagogical content knowledge in teachers' knowledge for teaching science (pp. 185-197). Singapore, Springer. https://doi.org/10.1007/ 978-981-13-5898-2_8

Park, S., Jang, J. Y., Chen, Y. C., \& Jung, J. (2011). Is pedagogical content knowledge (PCK) necessary for reformed science teaching? Evidence from an Empirical Study. Research in Science Education, 41, 245-260. https://doi.org/10.1007/s11165-009-9163-8

Park, S., Suh, J., \& Seo, K. (2018). Development and validation of measures of secondary science teachers' PCK for teaching photosynthesis. Research in Science Education, 48, 549-573. https://doi.org/10.1007/s11165-016-9578-y

Patton, M. Q. (2002). Qualitative Research \& Evaluation Methods (3rd ed.). Thousand Oaks, CA: Sage Publications.

Shulman, L. S. (2015). PCK: Its genesis and exodus. In A. Berry, P. Friedrichsen, \& J. Loughran (Eds.), Re-examining pedagogical content knowledge in science education (pp. 28-42). New York, NY: Routledge.

Tepner, O., \& Sumfleth, E. (2019). Postscript: considerations from an external perspective. In A. Hume, R. Cooper, \& A. Borowski (Eds.), Repositioning pedagogical content knowledge in teachers'knowledge for teaching science (pp. 223-250). Singapore, Springer. 
Van Driel, J. H., Berry, A., \& Meirink, J. A. (2014). Research on science teacher knowledge. In N. Lederman \& S. K. Abell (Eds.), Handbook of research on science education (2nd ed., pp. 848-870). London: Taylor \& Francis.

Vollebregt, B. R., Gaigher, E., \& Coetzee, C. (2021). Development of science teachers' PCK about waves through training in the use of the ripple tank apparatus. African Journal of Research in Mathematics, Science and Technology Education, 25(1), 12-26. https://doi.org/ 10.1080/18117295.2021.1892331

\section{Appendix A}

\section{Rubric for Analysing ePCK Profiles}

\begin{tabular}{|c|c|c|c|c|c|}
\hline \multirow{2}{*}{$\begin{array}{l}\text { ePCK } \\
\text { components }\end{array}$} & \multirow{2}{*}{$\begin{array}{l}\text { Evaluation criteria } \\
\text { across phases }\end{array}$} & \multicolumn{4}{|c|}{ Level of performance } \\
\hline & & Not applicable $(0)$ & Basic (1) & Developing (2) & Exemplary (3) \\
\hline \multirow{6}{*}{ 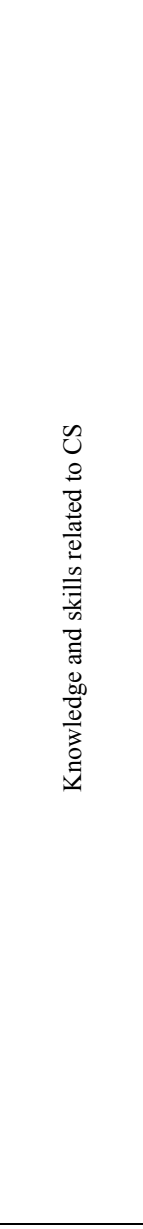 } & Content-Planning & $\begin{array}{l}\text { Inaccurate lesson } \\
\text { content relative to the } \\
\text { goals of the curriculum }\end{array}$ & $\begin{array}{l}\text { No alignment of } \\
\text { lesson content with the } \\
\text { goals of the curriculum }\end{array}$ & $\begin{array}{l}\text { Alignment of lesson } \\
\text { content with the goals } \\
\text { of the curriculum } \\
\text { without a clear } \\
\text { understanding of its } \\
\text { pedagogical value }\end{array}$ & $\begin{array}{l}\text { Well-aligned lesson } \\
\text { content with the goals } \\
\text { of the curriculum }\end{array}$ \\
\hline & Content-Teaching & $\begin{array}{l}\text { No attempt to make } \\
\text { lesson content } \\
\text { common for students } \\
\text { to learn }\end{array}$ & $\begin{array}{l}\text { No attempt to make } \\
\text { lesson content } \\
\text { common for students } \\
\text { to learn }\end{array}$ & $\begin{array}{l}\text { Attempts to make } \\
\text { lesson content } \\
\text { common for students } \\
\text { to learn by providing } \\
\text { broad rationales }\end{array}$ & $\begin{array}{l}\text { Attempts to make } \\
\text { lesson content } \\
\text { common for students } \\
\text { to learn }\end{array}$ \\
\hline & Content-Reflecting & $\begin{array}{l}\text { Inconsistency between } \\
\text { the planned and the } \\
\text { enacted lesson content }\end{array}$ & $\begin{array}{l}\text { Some consistent } \\
\text { incidents between the } \\
\text { planned and the } \\
\text { enacted lesson content }\end{array}$ & $\begin{array}{l}\text { Many consistent } \\
\text { incidents between the } \\
\text { planned and the } \\
\text { enacted lesson content }\end{array}$ & $\begin{array}{l}\text { Consistency between } \\
\text { the planned and the } \\
\text { enacted lesson content }\end{array}$ \\
\hline & Big ideas-Planning & $\begin{array}{l}\text { Inappropriate } \\
\text { selection of big ideas } \\
\text { relative to the } \\
\text { curriculum which are } \\
\text { incoherent }\end{array}$ & $\begin{array}{l}\text { Appropriate selection } \\
\text { of some big ideas } \\
\text { relative to the } \\
\text { curriculum which are } \\
\text { incoherent }\end{array}$ & $\begin{array}{l}\text { Appropriate selection } \\
\text { of many big ideas } \\
\text { relative to the } \\
\text { curriculum which are } \\
\text { coherent }\end{array}$ & $\begin{array}{l}\text { Appropriate selection } \\
\text { of big ideas relative to } \\
\text { the curriculum which } \\
\text { are coherent }\end{array}$ \\
\hline & Big ideas-Teaching & $\begin{array}{l}\text { No attempt to connect } \\
\text { big ideas across } \\
\text { horizontal and/or } \\
\text { vertical curriculum }\end{array}$ & $\begin{array}{l}\text { Attempts to make } \\
\text { broad connections } \\
\text { between big ideas and } \\
\text { horizontal or vertical } \\
\text { curriculum }\end{array}$ & $\begin{array}{l}\text { Attempts to make } \\
\text { broad connections } \\
\text { between big ideas and } \\
\text { horizontal and vertical } \\
\text { curriculum }\end{array}$ & $\begin{array}{l}\text { Attempts to make } \\
\text { students connect big } \\
\text { ideas across the } \\
\text { horizontal and vertical } \\
\text { curriculum }\end{array}$ \\
\hline & Big ideas-Reflecting & $\begin{array}{l}\text { Inconsistency between } \\
\text { the selected and the } \\
\text { enacted big ideas }\end{array}$ & $\begin{array}{l}\text { Some consistent } \\
\text { incidents between the } \\
\text { selected and the } \\
\text { enacted big ideas }\end{array}$ & $\begin{array}{l}\text { Many consistent } \\
\text { incidents between the } \\
\text { selected and the } \\
\text { enacted big ideas }\end{array}$ & $\begin{array}{l}\text { Consistency between } \\
\text { the selected and the } \\
\text { enacted big ideas }\end{array}$ \\
\hline & $\begin{array}{l}\text { Instructional strategies- } \\
\text { Planning }\end{array}$ & $\begin{array}{l}\text { Inappropriate } \\
\text { selection } \\
\text { of/inaccurate } \\
\text { strategies that fail to } \\
\text { facilitate student } \\
\text { understanding of the } \\
\text { specific science } \\
\text { concepts }\end{array}$ & $\begin{array}{l}\text { Appropriate selection } \\
\text { of strategies that fail to } \\
\text { facilitate student } \\
\text { understanding of the } \\
\text { specific science } \\
\text { concepts as they are } \\
\text { scientifically } \\
\text { inaccurate }\end{array}$ & $\begin{array}{l}\text { Appropriate selection } \\
\text { of accurate strategies } \\
\text { that facilitate student } \\
\text { understanding of the } \\
\text { specific science } \\
\text { concepts }\end{array}$ & $\begin{array}{l}\text { Appropriate selection } \\
\text { of accurate strategies } \\
\text { that facilitate student } \\
\text { understanding of the } \\
\text { specific science } \\
\text { concepts }\end{array}$ \\
\hline
\end{tabular}




\begin{tabular}{|c|c|c|c|c|c|}
\hline \multirow{5}{*}{ 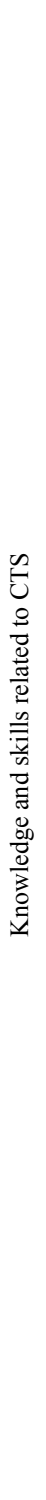 } & $\begin{array}{l}\text { Instructional strategies- } \\
\text { Teaching }\end{array}$ & $\begin{array}{l}\text { Inappropriate/inaccu } \\
\text { rate use of strategies } \\
\text { that fail to facilitate } \\
\text { student understanding } \\
\text { of the specific science } \\
\text { concepts }\end{array}$ & $\begin{array}{l}\text { Inappropriate/inaccu } \\
\text { rate use of strategies } \\
\text { that fail to facilitate } \\
\text { student understanding } \\
\text { of the specific science } \\
\text { concepts }\end{array}$ & $\begin{array}{l}\text { Inappropriate use of } \\
\text { accurate strategies } \\
\text { that fail to facilitate } \\
\text { student understanding } \\
\text { of the specific science } \\
\text { concepts }\end{array}$ & $\begin{array}{l}\text { Appropriate use of } \\
\text { accurate strategies } \\
\text { that facilitate student } \\
\text { understanding of the } \\
\text { specific science } \\
\text { concepts }\end{array}$ \\
\hline & $\begin{array}{l}\text { Instructional strategies- } \\
\text { Reflecting }\end{array}$ & $\begin{array}{l}\text { Inconsistency between } \\
\text { the selected and the } \\
\text { used instructional } \\
\text { strategies that facilitate } \\
\text { student understanding } \\
\text { of the specific science } \\
\text { concepts }\end{array}$ & $\begin{array}{l}\text { Some consistent } \\
\text { incidents between the } \\
\text { selected and the used } \\
\text { instructional strategies } \\
\text { that facilitate student } \\
\text { understanding of the } \\
\text { specific science } \\
\text { concepts }\end{array}$ & $\begin{array}{l}\text { Many consistent } \\
\text { incidents between the } \\
\text { selected and the used } \\
\text { instructional strategies } \\
\text { that facilitate student } \\
\text { understanding of the } \\
\text { specific science } \\
\text { concepts }\end{array}$ & $\begin{array}{l}\text { Consistency between } \\
\text { the selected and the } \\
\text { used instructional } \\
\text { strategies that facilitate } \\
\text { student understanding } \\
\text { of the specific science } \\
\text { concepts }\end{array}$ \\
\hline & $\begin{array}{l}\text { Representations- } \\
\text { Planning }\end{array}$ & $\begin{array}{l}\text { No recognition of } \\
\text { students' approaches to } \\
\text { learning and their } \\
\text { difficulties while } \\
\text { specifying } \\
\text { representations }\end{array}$ & $\begin{array}{l}\text { Some identification of } \\
\text { students' approaches to } \\
\text { learning and their } \\
\text { difficulties while } \\
\text { specifying } \\
\text { representations }\end{array}$ & $\begin{array}{l}\text { Adequate } \\
\text { identification of } \\
\text { students' approaches to } \\
\text { learning and their } \\
\text { difficulties while } \\
\text { specifying } \\
\text { representations }\end{array}$ & $\begin{array}{l}\text { Sophisticated } \\
\text { recognition of } \\
\text { students' approaches to } \\
\text { learning and their } \\
\text { difficulties while } \\
\text { specifying } \\
\text { representations }\end{array}$ \\
\hline & $\begin{array}{l}\text { Representations- } \\
\text { Teaching }\end{array}$ & $\begin{array}{l}\text { No attempt to use } \\
\text { representations that } \\
\text { facilitate student } \\
\text { understanding of the } \\
\text { specific science } \\
\text { concepts }\end{array}$ & $\begin{array}{l}\text { Some attempt to use } \\
\text { representations that } \\
\text { facilitate student } \\
\text { understanding of the } \\
\text { specific science } \\
\text { concepts }\end{array}$ & $\begin{array}{l}\text { Attempts to use } \\
\text { multiple } \\
\text { representations } \\
\text { without making links } \\
\text { to the specific science } \\
\text { concepts }\end{array}$ & $\begin{array}{l}\text { Attempts to use } \\
\text { multiple } \\
\text { representations that } \\
\text { facilitate student } \\
\text { understanding of the } \\
\text { specific science } \\
\text { concepts }\end{array}$ \\
\hline & $\begin{array}{l}\text { Representations- } \\
\text { Reflecting }\end{array}$ & $\begin{array}{l}\text { Inconsistency between } \\
\text { the recognized } \\
\text { approaches of students } \\
\text { to learning and their } \\
\text { difficulties while } \\
\text { specifying } \\
\text { representations and the } \\
\text { used representations }\end{array}$ & $\begin{array}{l}\text { Some consistent } \\
\text { incidents between the } \\
\text { recognized approaches } \\
\text { of students to learning } \\
\text { and their difficulties } \\
\text { while specifying } \\
\text { representations and the } \\
\text { used representations }\end{array}$ & $\begin{array}{l}\text { Many consistent } \\
\text { incidents between the } \\
\text { recognized approaches } \\
\text { of students to learning } \\
\text { and their difficulties } \\
\text { while specifying } \\
\text { representations and the } \\
\text { used representations }\end{array}$ & $\begin{array}{l}\text { Consistency between } \\
\text { the recognized } \\
\text { approaches of students } \\
\text { to learning and their } \\
\text { difficulties while } \\
\text { specifying } \\
\text { representations and the } \\
\text { used representations }\end{array}$ \\
\hline \multirow{3}{*}{ 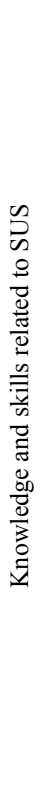 } & $\begin{array}{l}\text { Variations in student } \\
\text { learning-Planning }\end{array}$ & $\begin{array}{l}\text { No identification of } \\
\text { variations in how } \\
\text { different students may } \\
\text { learn the specific } \\
\text { science concepts }\end{array}$ & $\begin{array}{l}\text { Some identification of } \\
\text { variations in how } \\
\text { different students may } \\
\text { learn the specific } \\
\text { science concepts }\end{array}$ & $\begin{array}{l}\text { Adequate } \\
\text { identification of } \\
\text { variations in how } \\
\text { different students may } \\
\text { learn the specific } \\
\text { science concepts }\end{array}$ & $\begin{array}{l}\text { Sophisticated } \\
\text { identification of } \\
\text { variations in how } \\
\text { different students may } \\
\text { learn the specific } \\
\text { science concepts }\end{array}$ \\
\hline & $\begin{array}{l}\text { Variations in student } \\
\text { learning-Teaching }\end{array}$ & $\begin{array}{l}\text { No attempt to address } \\
\text { variations in how } \\
\text { different students may } \\
\text { learn the specific } \\
\text { science concepts }\end{array}$ & $\begin{array}{l}\text { No attempt to address } \\
\text { variations in how } \\
\text { different students may } \\
\text { learn the specific } \\
\text { science concepts }\end{array}$ & $\begin{array}{l}\text { Limited attempts to } \\
\text { address the variations } \\
\text { in how different } \\
\text { students may learn the } \\
\text { specific science } \\
\text { concepts }\end{array}$ & $\begin{array}{l}\text { Attempts to address } \\
\text { the variations in how } \\
\text { different students may } \\
\text { learn the specific } \\
\text { science concepts }\end{array}$ \\
\hline & $\begin{array}{l}\text { Variations in student } \\
\text { learning-Reflecting }\end{array}$ & $\begin{array}{l}\text { Inconsistency between } \\
\text { the identified and the } \\
\text { addressed variations in } \\
\text { how different students } \\
\text { may learn the specific } \\
\text { science concepts }\end{array}$ & $\begin{array}{l}\text { Some consistent } \\
\text { incidents between the } \\
\text { identified and the } \\
\text { addressed variations in } \\
\text { how different students } \\
\text { may learn the specific } \\
\text { science concepts }\end{array}$ & $\begin{array}{l}\text { Many consistent } \\
\text { incidents between the } \\
\text { identified and the } \\
\text { addressed variations in } \\
\text { how different students } \\
\text { may learn the specific } \\
\text { science concepts }\end{array}$ & $\begin{array}{l}\text { Consistency between } \\
\text { the identified and the } \\
\text { addressed variations in } \\
\text { how different students } \\
\text { may learn the specific } \\
\text { science concepts }\end{array}$ \\
\hline
\end{tabular}




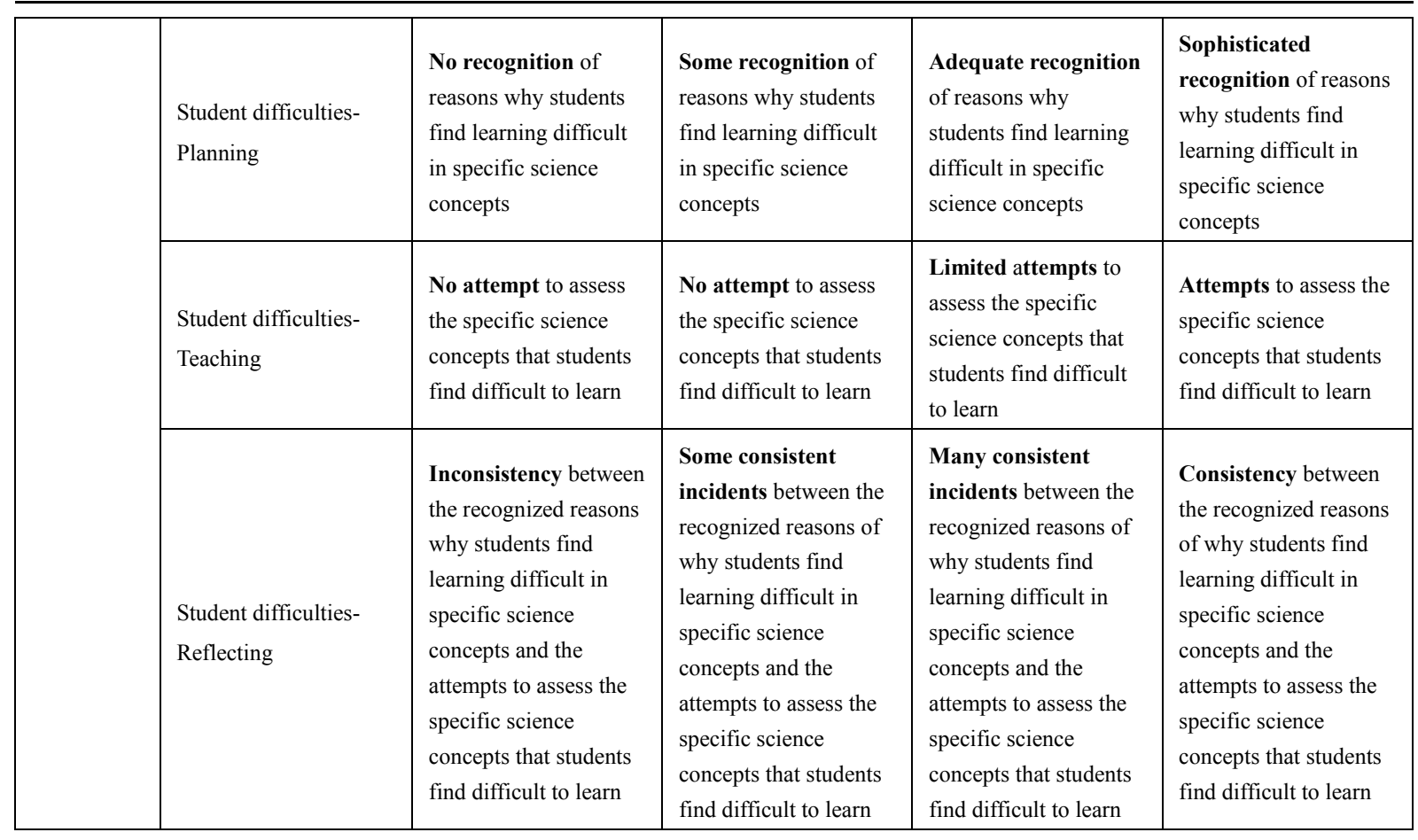

\section{Appendix B}

\section{Scoring Rubric}

\begin{tabular}{|l|l|}
\hline Level of Performance & Possible Teacher Points for each Phase of Pedagogical Cycle \\
\hline Not applicable & 0 points \\
\hline Basic & Points between 1 and 6 \\
\hline Developing & Points between 7 and 12 \\
\hline Exemplary & Points between 13 and 18 \\
\hline
\end{tabular}

\section{Copyright Disclaimer}

Copyright for this article is retained by the author(s), with first publication rights granted to the journal.

This is an open-access article distributed under the terms and conditions of the Creative Commons Attribution license (http://creativecommons.org/licenses/by/3.0/). 